Old Dominion University

ODU Digital Commons

2013

\title{
Combined Effects of CO2 and Light on Large and Small Isolates of the Unicellular N2-Fixing Cyanobacterium Crocosphaera watsonii From the Western Tropical Atlantic Ocean
}

Nathan S. Garcia

Fei-Xue Fu

Cynthia L. Breene

Elizabeth K. Yu

Peter W. Bernhardt

See next page for additional authors

Follow this and additional works at: https://digitalcommons.odu.edu/oeas_fac_pubs

Part of the Marine Biology Commons, Microbiology Commons, and the Oceanography and Atmospheric Sciences and Meteorology Commons

\section{Original Publication Citation}

Garcia, N. S., Fu, F. X., Breene, C. L., Yu, E. K., Bernhardt, P. W., Mulholland, M. R., \& Hutchins, D. A. (2013). Combined effects of $\mathrm{CO}_{2}$ and light on large and small isolates of the unicellular $\mathrm{N}_{2}$-fixing cyanobacterium Crocosphaera watsonii from the western tropical Atlantic Ocean. European Journal of Phycology, 48(1), 128-139. doi:10.1080/09670262.2013.773383

This Article is brought to you for free and open access by the Ocean \& Earth Sciences at ODU Digital Commons. It has been accepted for inclusion in OES Faculty Publications by an authorized administrator of ODU Digital Commons. For more information, please contact digitalcommons@odu.edu. 


\section{Authors}

Nathan S. Garcia, Fei-Xue Fu, Cynthia L. Breene, Elizabeth K. Yu, Peter W. Bernhardt, Margaret R. Mulholland, and David A. Hutchins 


\title{
Combined effects of $\mathrm{CO}_{2}$ and light on large and small isolates of the unicellular $\mathrm{N}_{2}$-fixing cyanobacterium Crocosphaera watsonii from the western tropical Atlantic Ocean
}

\author{
NATHAN S. GARCIA ${ }^{1}$, FEI-XUE FU ${ }^{1}$, CYNTHIA L. BREENE ${ }^{1}$, ELIZABETH K. YU ${ }^{1}$, PETER W. \\ BERNHARDT $^{2}$, MARGARET R. MULHOLLAND ${ }^{2}$ AND DAVID A. HUTCHINS ${ }^{1}$ \\ ${ }^{1}$ Department of Biological Sciences, University of Southern California, Los Angeles, CA 90089, USA \\ ${ }^{2}$ Department of Ocean, Earth and Atmospheric Sciences, Old Dominion University, Norfolk, VA 23529, USA
}

(Received 8 December 2011; revised 26 October 2012; accepted 30 October 2012)

\begin{abstract}
We examined the combined effects of light and $\mathrm{pCO}_{2}$ on growth, $\mathrm{CO}_{2}$-fixation and $\mathrm{N}_{2}$-fixation rates by strains of the unicellular marine $\mathrm{N}_{2}$-fixing cyanobacterium Crocosphaera watsonii with small (WH0401) and large (WH0402) cells that were isolated from the western tropical Atlantic Ocean. In low- $\mathrm{pCO}_{2}$-acclimated cultures (190 ppm) of WH0401, growth, $\mathrm{CO}_{2}$-fixation and $\mathrm{N}_{2}$ fixation rates were significantly lower than those in cultures acclimated to higher (present-day $\sim 385 \mathrm{ppm}$, or future $\sim 750 \mathrm{ppm}$ ) $\mathrm{pCO}_{2}$ treatments. Growth rates were not significantly different, however, in low-pCO $\mathrm{p}_{2}$-acclimated cultures of WH0402 in comparison with higher $\mathrm{pCO}_{2}$ treatments. Unlike previous reports for $C$. watsonii (strain $\mathrm{WH} 8501$ ), $\mathrm{N}_{2}$-fixation rates did not increase further in cultures of WH0401 or WH0402 when acclimated to $750 \mathrm{ppm}$ relative to those maintained at present-day $\mathrm{pCO}_{2}$. Both light and $\mathrm{pCO}_{2}$ had a significant negative effect on gross : net $\mathrm{N}_{2}$-fixation rates in $\mathrm{WH} 0402$ and trends were similar in WH0401, implying that retention of fixed $\mathrm{N}$ was enhanced under elevated light and $\mathrm{pCO}_{2}$. These data, along with previously reported results, suggest that $C$. watsonii may have wide-ranging, strain-specific responses to changing light and $\mathrm{pCO}_{2}$, emphasizing the need for examining the effects of global change on a range of isolates within this biogeochemically important genus. In general, however, our data suggest that cellular $\mathrm{N}$ retention and $\mathrm{CO}_{2}$-fixation rates of $C$. watsonii may be positively affected by elevated light and $\mathrm{pCO}_{2}$ within the next 100 years, potentially increasing trophic transfer efficiency of $\mathrm{C}$ and $\mathrm{N}$ and thereby facilitating uptake of atmospheric carbon by the marine biota.
\end{abstract}

Key words: carbon dioxide, Crocosphaera, cyanobacteria, diazotroph, light, nitrogen fixation, ocean global change, unicellular

\section{Introduction}

Within the past two decades, emerging data have suggested that the magnitude of marine $\mathrm{N}_{2}$ fixation has been grossly underestimated (Deutsch et al., 2007; Capone, 2008; Mulholland et al., 2012). Traditionally, Trichodesmium has been widely accepted to be a major contributor to oceanic $\mathrm{N}_{2}$ fixation; however, estimates of $\mathrm{N}_{2}$ fixation by unicellular diazotrophs continue to increase and their calculated $\mathrm{N}$ inputs to marine systems may narrow the gap in the global $\mathrm{N}$ budget (Zehr et al., 2001; Montoya et al., 2004; Church et al., 2008; Moisander et al., 2010). Understanding how these key components of the marine $\mathrm{N}$ cycle will respond to rapid global change is essential to predict how the carbon cycle will change.

In the next 100 years, anthropogenic inputs of $\mathrm{CO}_{2}$ to the atmosphere will likely double the present-day partial pressure of $\mathrm{CO}_{2}\left(\mathrm{pCO}_{2}\right)$. At the same time, the

Correspondence to: David A. Hutchins. E-mail: dahutch@usc.edu average global mixed layer depth is also expected to decrease, thereby contributing to higher mean light intensity experienced by phytoplankton (Sarmiento et al., 2004; Behrenfeld et al., 2006; Boyd et al., 2010). In addition to their individual effects, we now recognize that interactive effects of these and other environmental factors must be considered to realistically predict the net impacts of global change (Hutchins et al., 2007, 2009; Fu et al., 2008; Kranz et al., 2010; Levitan et al., 2010; Garcia et al., 2011). Crocosphaera watsonii has been widely studied in the literature in an effort to understand the physiology of unicellular photosynthetic $\mathrm{N}_{2}$ fixers and biogeochemical implications for models of oceanic biological $\mathrm{N}_{2}$ fixation (Zehr et al., 2001, 2007; Goebel et al., 2007, 2008). In this study, we examined how two isolates of this genus might respond to global change.

Previous studies suggest that elevated $\mathrm{pCO}_{2}$ acts to enhance gross $\mathrm{N}_{2}$-fixation rates by the oceanic diazotrophs Trichodesmium erythraeum and C. watsonii (Barcelos e Ramos et al., 2007; Hutchins et al., 
2007; Levitan et al., 2007; Fu et al. 2008). Recently, however, several experiments have indicated that light influences the effect of elevated $\mathrm{pCO}_{2}$ on gross $\mathrm{N}_{2}$ fixation by T. erythraeum (Kranz et al., 2010; Garcia et al., 2011). Elevated $\mathrm{pCO}_{2}$ acts to enhance $\mathrm{N}_{2}$-fixation rates under low light but this stimulatory effect is lower at high light, which may be caused by an enhanced ability to retain newly fixed cellular $\mathrm{N}$ at high light (Garcia et al., 2011).

Our goal in this study was to understand how light influences the effect of elevated $\mathrm{CO}_{2}$ on growth, $\mathrm{CO}_{2}$-fixation and $\mathrm{N}_{2}$-fixation rates of two isolates of C. watsonii from the western tropical Atlantic Ocean in laboratory culture experiments. To date, most published works investigating the physiological responses of $C$. watsonii have focused on one strain (WH8501) and physiological studies of other strains are currently lacking. Recently, Webb et al. (2009) compared $\mathrm{N}_{2-}$ fixation rates by strains of $C$. watsonii differing in cell size. Chl $a$-normalized $\mathrm{N}_{2}$-fixation rates in a large strain isolated from the North Pacific Ocean (WH0003) were twice as high as those in a smaller strain isolated from the South Atlantic Ocean (WH8501). To consider differences in responses between strains of $C$. watsonii, we examined one isolate with small cells $(2-3 \mu \mathrm{m}$ diameter; WH0401) and another isolate with large cells (4-6 $\mu$ m diameter; WH0402).

\section{Materials and methods}

\section{Culturing and experimental design}

Stock cultures of the two Atlantic $C$. watsonii isolates used in this study were provided courtesy of Dr. Eric Webb. Both isolates were collected in March 2002, WH0401 from $6^{\circ} 58.78^{\prime} \mathrm{N}, 49^{\circ} 19.70^{\prime} \mathrm{W}$ and $\mathrm{WH} 0402$ from $11^{\circ} 42.12 \mathrm{~S}^{\prime}, 32^{\circ}$ $00.64^{\prime} \mathrm{W}$. An outline of all experiments with both isolates, including experimental analyses used for each, is presented in Table 1. In all experiments, triplicate cultures were grown using a semi-continuous culturing technique (Garcia et al., 2011) at $28^{\circ} \mathrm{C}$ in an artificial seawater medium (Chen et al., 1996). Nutrients were added to autoclaved seawater at the concentrations listed in the AQUIL recipe (Morel et al., 1979), except for nitrate, which was omitted. The growth rates of cultures were measured over 2-3 day intervals and were used to determine the dilution rate. Culture cell density was kept low (cells ml ${ }^{-1}=50-500 \times 10^{3}$ for experiments with WH0401 and 5.0-30 $\times 10^{3}$ for WH0402; Table 1) to prevent light limitation of photosynthesis and deviation from the expected $\mathrm{pH}$ values for respective $\mathrm{pCO}_{2}$ culture treatments. Light was supplied with cool-white fluorescent lamps on a $12: 12 \mathrm{~h} \mathrm{light} \mathrm{:} \mathrm{dark} \mathrm{cycle} \mathrm{and} \mathrm{measured} \mathrm{with} \mathrm{a} \mathrm{LI-250A} \mathrm{light}$ meter (LiCor Biosciences, light sensor serial\# SPQA 4020). Because of large differences in cell size between WH0401 and WH0402, we cultured WH0401 at higher cell densities to maintain relatively equivalent levels of total culture biomass (0.1-2.5 mM particulate $\mathrm{C}$ for cultures of WH0401; 0.1-1.3 mM particulate $\mathrm{C}$ for $\mathrm{WH} 0402$ ). For $\mathrm{CO}_{2}$ experiments, media and cultures were bubbled with filtered air from the room $\left(0.2 \mu \mathrm{m}\right.$ filtered, present-day $\mathrm{pCO}_{2}$ concentration of $\sim 385 \mathrm{ppm}$ ) or premixed air prepared by Gilmore Liquid Air Company with certified values of $190 \mathrm{ppm} \mathrm{pCO}_{2}$ (last glacial maximum levels: Petit et al., 1999) and 750 or $761 \mathrm{ppm} \mathrm{pCO}_{2}$ (within the range predicted for the year 2100: Alley et al., 2007) for the entire term of the experiment (Table 1). Cells were considered fully acclimated to treatment conditions after cultures had remained at steady-state growth for seven generations or more (unless stated otherwise). Fastgrowing cultures (i.e. high light cultures) were acclimated for more than 10 generations while slow growing cultures (i.e. low light and low $\mathrm{pCO}_{2}$ cultures) were acclimated over 2 months but for fewer generations. Cultures were sampled over the period between 24 and $48 \mathrm{~h}$ after the preceding dilution to measure growth rates, gross and net ${ }^{15} \mathrm{~N}_{2}$-fixation rates, $\mathrm{CO}_{2}$-fixation rates, particulate elemental composition, and carbonate system measurements (for $\mathrm{CO}_{2}$ experiments).

\section{Light experiments}

In order to quantify differences in growth and in the $\mathrm{CO}_{2}$ - and $\mathrm{N}_{2}$-fixation rate capacities of these two isolates of $C$. watsonii, we measured growth, $\mathrm{CO}_{2}$-fixation and gross and net $\mathrm{N}_{2}$-fixation rates, and particulate carbon and nitrogen composition in response to a range of light intensities (labelled experiments 1 and 2 in Table 1).

Table 1. Outline of experiments (1-6) with Crocosphaera watsonii strains WH0401 and WH0402. The analyses made were (a) growth rates, (b) $\mathrm{CO}_{2}$-fixation rates, ( $c^{1}$ ) 12-h gross $\mathrm{N}_{2}$-fixation rates, ( $\mathrm{c}^{2}$ ) 4-h gross $\mathrm{N}_{2}$-fixation rates, $\left(\mathrm{c}^{3}\right)$ 14-h gross $\mathrm{N}_{2}$-fixation rates, (d) ${ }^{15} \mathrm{~N}_{2}$-fixation rates, (e) particulate elemental composition, (f) cell diameter measurements, (g) particulate $\mathrm{N}$ accumulation rates, (h) $\mathrm{pH}$ measurements, and (i) total $\mathrm{CO}_{2}$ measurements.

\begin{tabular}{|c|c|c|c|c|c|c|}
\hline Experiment & Isolate & $\begin{array}{l}\text { Light } \\
\left(\mu \mathrm{mol} \text { quanta } \mathrm{m}^{-2} \mathrm{~s}^{-1}\right)\end{array}$ & $\begin{array}{l}\mathrm{CO}_{2} \\
(\mathrm{ppm})\end{array}$ & $\begin{array}{c}\text { Cell density } \\
\left(\text { cells ml }{ }^{-1}\right)\left(\times 10^{4}\right)\end{array}$ & $\begin{array}{c}\text { Biovolume } \\
\left(\mu \mathrm{m}^{-3} \mathrm{ml}^{-1}\right)\left(\times 10^{5}\right)\end{array}$ & Analyses \\
\hline \multicolumn{7}{|c|}{ Light experiments } \\
\hline 1 & WH0401 & $25,50,100,180,300$ & non-bubbled & $5.0-30$ & $4.1-24.5$ & $a, b, c^{1}, d, e, f$ \\
\hline 2 & WH0402 & $25,50,100,180,300$ & non-bubbled & $1.0-3.0$ & $6.5-19.6$ & $\mathrm{a}, \mathrm{b}, \mathrm{c}^{1}, \mathrm{~d}, \mathrm{e}, \mathrm{f}$ \\
\hline \multicolumn{7}{|c|}{$\mathrm{CO}_{2}$ experiment } \\
\hline 3 & WH0401 & 155 & 190, air, 750 & $15-30$ & $15-30$ & $a, c^{2}, d, h$ \\
\hline 4 & WH0402 & 155 & 190 , air, 750 & $0.5-2.0$ & $3.27-13.1$ & $\mathrm{a}, \mathrm{c}^{2}, \mathrm{~d}, \mathrm{~h}$ \\
\hline \multicolumn{7}{|c|}{$\mathrm{CO}_{2}$-light experiments } \\
\hline 5 & WH0401 & $100,180,300$ & 190, air, 761 & $15-50$ & $12.3-40.9$ & $\mathrm{a}, \mathrm{b}, \mathrm{c}^{3}, \mathrm{~d}, \mathrm{e}, \mathrm{g}, \mathrm{h}, \mathrm{i}$ \\
\hline 6 & WH0402 & $18,50,100,180,300$ & Air, 750 & $1.0-3.0$ & $6.5-19.6$ & $\mathrm{a}, \mathrm{b}, \mathrm{c}^{1}, \mathrm{~d}, \mathrm{e}, \mathrm{g}, \mathrm{h}, \mathrm{i}$ \\
\hline
\end{tabular}




\section{$\mathrm{CO}_{2}$ experiments}

To investigate variability in the effects of $\mathrm{CO}_{2}$ on growth and $\mathrm{N}_{2}$-fixation rates between strains of $C$. watsonii, we conducted experiments with cultures of WH0401 and WH0402. We measured growth and gross and net $\mathrm{N}_{2}$-fixation rates (see $\mathrm{N}_{2}$-fixation rates) in response to three levels of $\mathrm{CO}_{2}$ $(190$, air and $750 \mathrm{ppm})$ at a light intensity of $155 \mu \mathrm{mol}$ quanta $\mathrm{m}^{-2} \mathrm{~s}^{-1}$ (labelled experiments 3 and 4 in Table 1). We chose this light intensity because we did not want growth rates in these cultures to be limited by light.

\section{$\mathrm{CO}_{2}$-light experiments}

To determine if light influences the effect of elevated $\mathrm{pCO}_{2}$ on growth, $\mathrm{CO}_{2}$-fixation and $\mathrm{N}_{2}$-fixation rates of $C$. watsonii, we first grew WH0402 with two concentrations of $\mathrm{CO}_{2}$ (air and $750 \mathrm{ppm}$ ) at five light intensities (18-300 $\mu \mathrm{mol}$ quanta $\mathrm{m}^{-2} \mathrm{~s}^{-1}$; labelled experiment 6 in Table 1). In this experiment we measured similar growth and $\mathrm{N}_{2}$-fixation rates at the two $\mathrm{CO}_{2}$ concentrations. Therefore, when examining responses of WH0401 with this experimental design, we added a low $\mathrm{CO}_{2}$ treatment $(190 \mathrm{ppm})$ under the same range of light intensities (labelled experiment 5 in Table 1). Despite several attempts, we were not able to acclimate WH0401 to any of these $\mathrm{CO}_{2}$ concentrations at 18 or $50 \mu \mathrm{mol}$ quanta $\mathrm{m}^{-2} \mathrm{~s}^{-1}$ for unknown reasons.

\section{Growth rate and cell density estimates}

Growth rate was determined as an increase in culture cell density over time with the equation $\mathrm{N}_{\mathrm{T}}=\mathrm{N}_{0} \mathrm{e}^{\mu \mathrm{T}}$, where $\mathrm{N}_{0}$ and $\mathrm{N}_{\mathrm{T}}$ are the initial and final culture cell densities, respectively, $\mathrm{T}$ is the time in days between culture cell density estimates, and $\mu$ is the specific growth rate. Culture cell density was determined using a haemocytometer and an Olympus BX51 microscope. Cell diameter was measured using an ocular micrometer calibrated with the same microscope. Growth rates were fitted to a Monod linear hyperbolic function of light (Monod, 1949) using Sigma Plot 10 software program. The hyperbola was fit to the data without including the origin to yield the highest $r^{2}$ value. With Sigma Plot 10 , we did this by calculating the $\mathrm{K}_{\mu}$ and maximum rate values after aligning the data to include the origin. The point of alignment was determined by achieving the highest $r^{2}$ value. We then realigned the data to their original values along with the best-fit functions. This method yields more realistic Monod parameters with critical threshold values.

\section{Carbonate system measurements}

Culture $\mathrm{pH}$ was measured intermittently during the $\mathrm{CO}_{2}$ experiments with a $\mathrm{pH}$ meter using the NBS seawater scale (Orion 5 star Thermo Scientific, Beverly, MA, USA). We preserved samples for total $\mathrm{CO}_{2}\left(\mathrm{TCO}_{2}\right)$ measurements in unfiltered water collected from cultures $(5-70 \mathrm{ml}$; stored at $4{ }^{\circ} \mathrm{C}$ ) with a $5 \% \mathrm{HgCl}_{2}$ solution $(0.5 \%$ final concentration) until later analysis with a carbon coulomb meter (CM 140, UIC, Joliet, IL, USA). We measured $\mathrm{TCO}_{2}$ by acidifying a $5 \mathrm{ml}$ sample with phosphoric acid (1-2\% final concentration) and quantifying the $\mathrm{CO}_{2}$ trapped in an acid sparging column as described in Garcia et al. (2011). $\mathrm{TCO}_{2}$ analyses were not available in our preliminary $\mathrm{CO}_{2}$ experiments. We calculated $\mathrm{pCO}_{2}$ with the $\mathrm{CO}_{2}$ sys program (Lewis \& Wallace, 1998) using the NBS $\mathrm{pH}$ scale and $\mathrm{K}_{1}$ and $\mathrm{K}_{2}$ constants from Mehrbach et al. (1973), refit by Dickson \& Millero (1987).

\section{$\mathrm{N}_{2}$ fixation}

For all experiments we used the acetylene reduction assay described by Capone (1993) to estimate the gross $\mathrm{N}_{2}$-fixation rate. All rate measurements in the light and $\mathrm{CO}_{2}$-light experiments were initiated at the beginning of the 12-h dark period, when $C$. watsonii is known to fix $\mathrm{N}_{2}$ (Mohr et al., 2010a; Saito et al., 2011). For the $\mathrm{CO}_{2}$ experiments the acetylene assay was initiated during the seventh hour of the 12-h dark period and continued for $4 \mathrm{~h}$. For this assay, two $50 \mathrm{ml}$ (light and $\mathrm{CO}_{2}$-light experiments) or $60 \mathrm{ml}\left(\mathrm{CO}_{2}\right.$ experiments) culture samples were collected from each replicate and incubated in $80-\mathrm{ml}$ polycarbonate bottles at $28^{\circ} \mathrm{C}$. Four millilitres of acetylene were injected into the headspace $\sim 1 \mathrm{~h}$ after the beginning of the dark period and samples were withdrawn from the headspace every $2-3 \mathrm{~h}$ to measure acetylene reduction. In the $\mathrm{CO}_{2}$-light experiment with $\mathrm{WH} 0401$, we measured rates throughout the dark period and continued to measure them during the early portion of the light cycle, when samples were exposed to treatment light levels (Table 1). In this experiment, we gently agitated incubation bottles to equilibrate ethylene in the seawater with ethylene in the headspace. Gross $\mathrm{N}_{2}$-fixation rates were calculated in the same way as described in Garcia et al. (2011), using a Bunsen coefficient for ethylene of 0.082 (Breitbarth et al., 2004) and an ethylene production : $\mathrm{N}_{2}$-fixation ratio of $3: 1$.

We also measured net $\mathrm{N}_{2}$-fixation rates using the ${ }^{15} \mathrm{~N}_{2}$ isotope tracer method (Mulholland et al., 2004; Mulholland $\&$ Bernhardt, 2005). Samples were prepared the same way as described in Garcia et al. (2011). Briefly, $169 \mathrm{ml}$ of each experimental replicate was inoculated with $169 \mu \mathrm{l}$ of $99 \%$ doubly labelled ${ }^{15} \mathrm{~N}_{2}$ gas and incubated at $28{ }^{\circ} \mathrm{C}$ in complete darkness for $12 \mathrm{~h}$ during the dark period. The incubation was then terminated by filtering the entire volume onto precombusted $\left(450^{\circ} \mathrm{C}, 4 \mathrm{~h}\right) \mathrm{GF} / \mathrm{F}$ filters for the analysis of particulate ${ }^{15} \mathrm{~N}$, total particulate $\mathrm{N}$ and total particulate C. Filters were dried at $80-90^{\circ} \mathrm{C}$, pelleted, and combusted in a quartz column with chromium oxide and silver wool at $1000^{\circ} \mathrm{C}$. For this analysis we used ammonium sulphate and sucrose as standards. At the time we conducted these experiments, we were not aware of the criticisms of the ${ }^{15} \mathrm{~N}_{2}$ uptake method that have been discussed by Mohr et al. (2010b). Thus, for another independent estimate of net $\mathrm{N}_{2}$ fixation, we calculated a particulate $\mathrm{N}(\mathrm{PN})$ accumulation rate in cultures over time $\left(\triangle \mathrm{PN}=\mathrm{PN}_{\text {final }}-\mathrm{PN}_{\text {initial }}\right)$ by using our estimates of particulate N. Particulate $N$ was measured in subsamples of experimental replicates that were incubated with ${ }^{15} \mathrm{~N}_{2}$ at the end of the dark period and used as the end-period PN measurement $\left(\mathrm{PN}_{\text {final }}\right)$. Because only one sample of $\mathrm{PN}$ was collected, we back-calculated an estimate of $\mathrm{PN}_{\text {initial }}$ based on our measurements of cellular growth rate using the equation: growth rate $\left(\mathrm{d}^{-1}\right)=\left[\ln \left(\mathrm{PN}_{\text {final }}\right)-\ln \left(\mathrm{PN}_{\text {initial }}\right)\right] /\left(t_{2}-t_{1}\right)$, where $t_{1}$ is the initial time and $t_{2}$ is the final time. Based on our measurements of growth rates, we assumed that $\mathrm{PN}$ cell ${ }^{-1}$ was in a daily steady state. We then calculated the gross $\mathrm{N}_{2}$-fixation rate : $\mathrm{PN}$-accumulation rate ratio (hereafter the gross : PN accumulation ratio) and compared it with the ratio of gross $\mathrm{N}_{2}$-fixation rate : net ${ }^{15} \mathrm{~N}_{2}$-fixation rate ratio 
(gross : net), which is a proxy for cellular $\mathrm{N}$ retention (Mulholland et al., 2004; Mulholland, 2007).

\section{$\mathrm{CO}_{2}$ fixation}

The rate of $\mathrm{CO}_{2}$ fixation was determined as described in Garcia et al. (2011) using the $\mathrm{H}^{14} \mathrm{CO}_{3}{ }^{-}$incorporation method. $\mathrm{CO}_{2}$-fixation rates were determined by first calculating the ratio of the radioactivity of ${ }^{14} \mathrm{C}$ incorporated into cells during $24 \mathrm{~h}$ to the total radioactivity of $\mathrm{H}^{14} \mathrm{CO}_{3}{ }^{-}$. This ratio was then multiplied by the total $\mathrm{CO}_{2}$ concentration $\left(\mathrm{TCO}_{2}\right) . \mathrm{TCO}_{2}$ concentrations were measured in our $\mathrm{CO}_{2}$-light experiments and were applied to all experiments to calculate $\mathrm{CO}_{2}$-fixation rates for corresponding $\mathrm{CO}_{2}$ treatments. For the light experiments, we used a $\mathrm{TCO}_{2}$ value that was measured in the present-day $\mathrm{pCO}_{2}$ treatments of the $\mathrm{CO}_{2}$-light experiments $(2053 \mu \mathrm{M} \mathrm{TCO} 2)$.

\section{Particulate $C$ and $N$}

Culture samples from each experimental replicate $(100 \mathrm{ml})$ were filtered onto precombusted $\left(450^{\circ} \mathrm{C}, 4 \mathrm{~h}\right) \mathrm{GF} / \mathrm{F}$ filters for the analysis of cellular $\mathrm{N}$ and $\mathrm{C}$. Filters were then dried at $80-90^{\circ} \mathrm{C}$ and compressed into pellets, and the amounts of $\mathrm{C}$ and $\mathrm{N}$ were determined using an elemental analyser (Costech Instruments, model 4010).

\section{Statistics}

We used a one-way analysis of variance (ANOVA) test (with the light experiment and $\mathrm{CO}_{2}$ experiment data) and a twoway ANOVA test (with the $\mathrm{CO}_{2}$-light experiment data) combined with a Tukey analysis of multiple comparisons to determine statistical differences $(P<0.05)$ between treatments. For these analyses, we used data from all three replicates from each treatment.

\section{Results}

\section{Light experiments (experiments 1 and 2)}

Mean specific growth rates of WH0402 were higher than those of WH0401 at all light levels investigated $(P<0.05$; Fig. 1a). Cells of WH0401 were considerably smaller than cells of WH0402 and average cell diameters were $\sim 20 \%$ larger in high-light acclimated cells compared to low-light acclimated cells in both strains $(P<0.05)$ (Fig. 1b). The Monod fit of growth as a function of light yielded a theoretical maximum growth rate of $0.95 \mathrm{~d}^{-1}\left(r^{2}=0.99\right)$ for WH0402 and $0.68 \mathrm{~d}^{-1}$ $\left(r^{2}=0.99\right)$ for WH0401. However, the half-saturation constant for growth $\left(\mathrm{K}_{\mu}\right)$ with respect to light and the light compensation point for growth $\left(\mathrm{E}_{\mathrm{c}}\right.$, where net growth is zero) were similar between strains (WH0401, $\mathrm{K}_{\mu}=61 \mu \mathrm{mol}$ quanta $\mathrm{m}^{-2} \mathrm{~s}^{-1}, \mathrm{E}_{\mathrm{c}}=11$ $\mu$ mol quanta $\mathrm{m}^{-2} \mathrm{~s}^{-1} ; \mathrm{WH} 0402, \mathrm{~K}_{\mu}=59 \mu \mathrm{mol}$ quanta $\mathrm{m}^{-2} \mathrm{~s}^{-1}, \mathrm{E}_{\mathrm{c}}=13 \mu \mathrm{mol}$ quanta $\left.\mathrm{m}^{-2} \mathrm{~s}^{-1}\right)$. Because of the large differences in cell size between strains, we compared $\mathrm{C}$-specific $\mathrm{CO}_{2}$-fixation rates and $\mathrm{N}$-specific $\mathrm{N}_{2}$-fixation rates. We determined these rates by normalizing $\mathrm{N}_{2}$-fixation rates to particulate organic nitrogen measurements and $\mathrm{CO}_{2}$ fixation rates to particulate organic carbon measurements. Both $\mathrm{C}$-specific $\mathrm{CO}_{2}$-fixation rates (Fig. 1c) and $\mathrm{N}$-specific gross $\mathrm{N}_{2}$-fixation rates (Fig. 1d) were consistently higher in the strain with large cells (WH0402) than in the strain with small cells (WH0401), except at the lowest light level, similar to the pattern of their specific growth rates. Mean growth rates were highly correlated with mean $\mathrm{N}$-specific ${ }^{15} \mathrm{~N}_{2}$-fixation rates $(r=0.85, n=5$ for WH0401; $r=0.99, n=5$ for WH0402) (Fig. 1a, e). Mean gross : net $\mathrm{N}_{2}$-fixation rate ratios declined with increasing light intensity by $72 \%$ in WH0401 (from 300 to $50 \mu \mathrm{mol}$ quanta $\mathrm{m}^{-2} \mathrm{~s}^{-1}$ ) and $82 \%$ in WH0402 (from 300 to $25 \mu \mathrm{mol}$ quanta $\mathrm{m}^{-2} \mathrm{~s}^{-1}$ ) and were negatively correlated with mean specific growth rates (WH0401, $r=-0.91, n=4$; WH0402, $r=-0.92$, $n=5$ ) and mean cell volumes (WH0401, $r=-0.89$, $n=4$; WH0402, $r=-0.71, n=5$; Fig. 1f).

\section{$\mathrm{CO}_{2}$ experiments (experiments 3 and 4 )}

For unknown reasons, the growth rates of WH0401 were lower in the $\mathrm{CO}_{2}$ experiment than in the $\mathrm{CO}_{2}$-light experiment with the same $\mathrm{CO}_{2}$ concentrations at relatively equivalent light intensities. Measured $\mathrm{pH}$ values in bubbled cultures of the $\mathrm{CO}_{2}$ experiments were comparable to bubbled cultures in the $\mathrm{CO}_{2}$-light experiments (Table 2). The partial pressure of $\mathrm{CO}_{2}$ did not have a significant effect on growth rates in the isolate with large cells (WH0402; $P>0.05$; Fig. 2). In contrast, growth rates in the small-celled strain (WH0401) were significantly lower at $190 \mathrm{ppm}$ $\mathrm{pCO}_{2}$ than those at higher $\mathrm{pCO}_{2}$ concentrations $(P<0.002$; Fig. 2$)$ but were not significantly different between the present-day and elevated $\mathrm{pCO}_{2}$ treatments $(P>0.05)$. Mean gross : net $\mathrm{N}_{2}$-fixation rate ratios decreased with increasing $\mathrm{pCO}_{2}$ by $42 \%$ for WH0401 $\left(F_{2,6}=4.2, P=0.07\right)$ and $27 \%$ for WH0402 $\left(F_{2,6} \geq 5.8, P \leq 0.04\right)$ and were negatively correlated with mean specific growth rates in both isolates (for both isolates $r=-0.99, n=3$; Fig. 2).

\section{$\mathrm{CO}_{2}$-light experiments (experiments 5 and 6)}

Measured $\mathrm{TCO}_{2}$ concentrations and $\mathrm{pH}$ values in our cultures were within the expected range for the respective $\mathrm{pCO}_{2}$ treatments (Table 2). The specific growth rates of WH0401 were significantly lower in the low $\mathrm{pCO}_{2}$ treatment than in higher $\mathrm{pCO}_{2}$ treatments $\left(F_{1,18}>55, P<0.001\right.$; Fig. $\left.3 a\right)$ but were not significantly different between the present-day and elevated $\mathrm{pCO}_{2}$ treatments $\left(F_{1,18}=0.20, P=0.66\right)$. The growth rates of WH0402 were not significantly different between the present-day and elevated $\mathrm{pCO}_{2}$ treatments at all light intensities that we investigated $\left(F_{1,20}=3.2, P=0.09\right.$; Fig. $\left.3 b\right)$. Cell-normalized $\mathrm{CO}_{2}$-fixation rates were positively affected by $\mathrm{pCO}_{2}$ in WH0401 $\left(F_{2,18}=4.7, P=0.02\right)$, but the interactive 


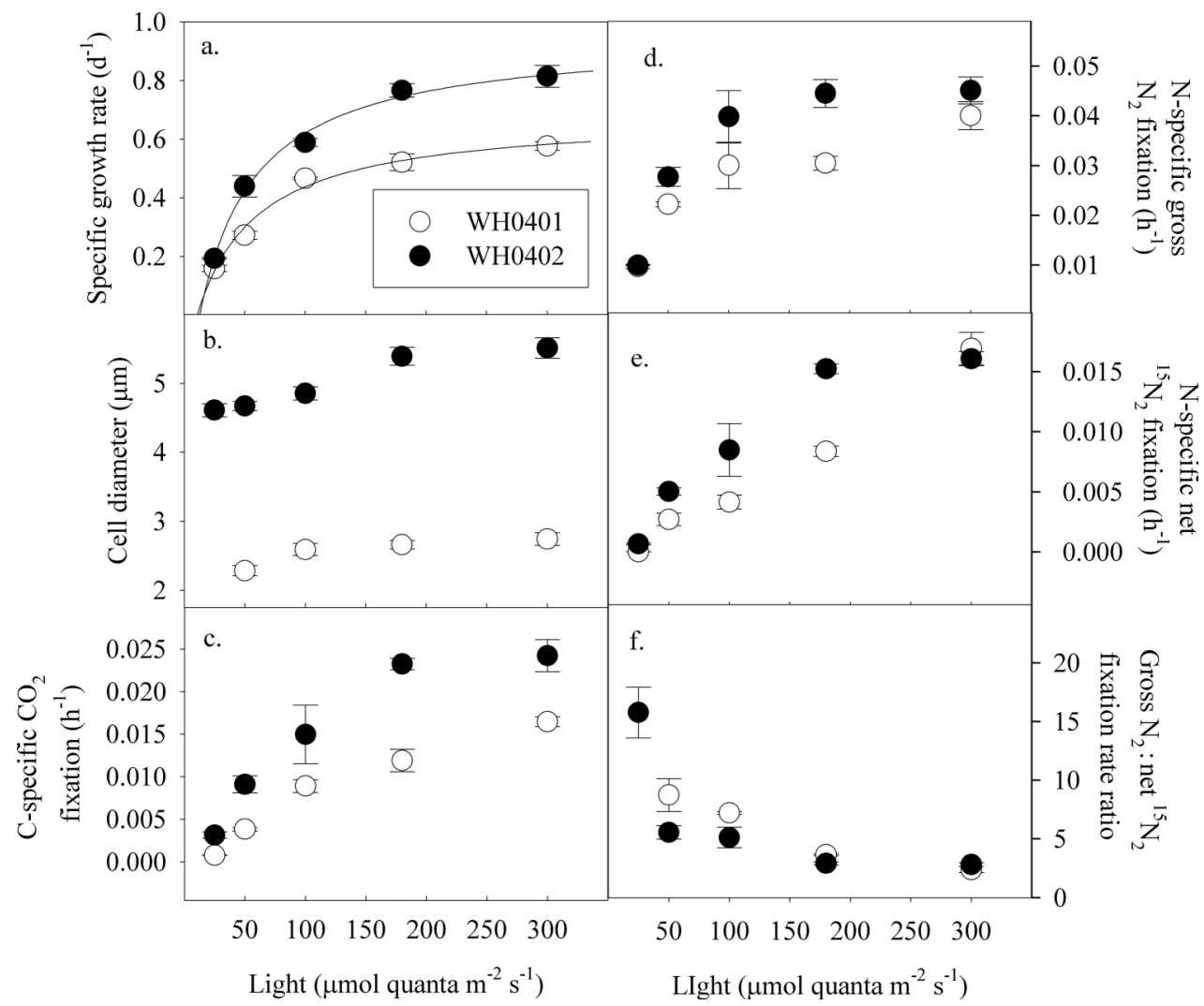

Fig. 1. Specific growth rates $\left(\mathrm{d}^{-1}\right)$ (a), cell diameter $(\mu \mathrm{m})(\mathrm{b})$, carbon-specific $\mathrm{CO}_{2}$-fixation rates (c), $\mathrm{N}$-specific gross $\mathrm{N}_{2}$-fixation rates (d), $\mathrm{N}$-specific net $\mathrm{N}_{2}$-fixation rates (e), and gross : net $\mathrm{N}_{2}$-fixation rate ratios (f) of Crocosphaera watsonii, isolates WH0401 and WH0402, in response to light $\left(25-300 \mu \mathrm{mol}\right.$ quanta $\left.\mathrm{m}^{-2} \mathrm{~s}^{-1}\right)$. Data correspond to experiments 1 and 2 in Table 1. Isolates were grown with a semi-continuous culturing method. Open symbols are WH0401; closed symbols are WH0402. Error bars are the standard errors of the means of three experimental replicates.

Table 2. Carbonate system measurements. The certified partial pressure of $\mathrm{CO}_{2}\left(\mathrm{pCO}_{2}\right)$ of pre-mixed air is given for treatments of low and elevated $\mathrm{pCO}_{2}$. The $\mathrm{pCO}_{2}$ of air was not measured. The $\mathrm{pCO}_{2}$ * was calculated for the $\mathrm{CO}_{2}-$ light experiments using the $\mathrm{CO}_{2}$ sys program (Lewis \& Wallace, 1998). Total inorganic carbon $\left(\mathrm{TCO}_{2}\right)$ was measured in the $\mathrm{CO}_{2}$-light experiments (experiments 5 and 6) and $\mathrm{pH}$ was measured in experiments 3-6. The standard deviation (SD) is reported on the mean of three treatment replicates in steady-state semi-continuous cultures of Crocosphaera watsonii; n.d. = no data.

\begin{tabular}{|c|c|c|c|c|c|c|c|c|}
\hline Experiment & Strain & $\mathrm{pCO}_{2}(\mathrm{ppm})$ & $\mathrm{pH}$ & SD & $\mathrm{TCO}_{2}(\mu \mathrm{M})$ & SD & $\mathrm{pCO}_{2} *(\mathrm{ppm})$ & SD \\
\hline \multicolumn{9}{|c|}{ Preliminary $\mathrm{CO}_{2}$ experiments } \\
\hline \multirow[t]{3}{*}{3} & \multirow[t]{3}{*}{ WH0401 } & 190 & 8.43 & 0.03 & n.d. & & & \\
\hline & & Air $(\sim 386)$ & 8.19 & 0.00 & n.d. & & & \\
\hline & & 750 & 8.01 & 0.01 & n.d. & & & \\
\hline \multirow[t]{3}{*}{4} & \multirow{3}{*}{ WH0402 } & 190 & 8.40 & 0.01 & n.d. & & & \\
\hline & & Air $(\sim 386)$ & 8.14 & 0.01 & n.d. & & & \\
\hline & & 750 & 8.01 & 0.01 & n.d. & & & \\
\hline \multicolumn{9}{|c|}{$\mathrm{CO}_{2}$-light experiments } \\
\hline \multirow[t]{3}{*}{5} & \multirow[t]{3}{*}{ WH0401 } & 190 & 8.45 & 0.01 & 1748 & 23 & 181 & 6 \\
\hline & & $\operatorname{Air}(\sim 386)$ & 8.21 & 0.01 & 2017 & 35 & 394 & 16 \\
\hline & & 761 & 8.02 & 0.01 & 2128 & 19 & 674 & 24 \\
\hline \multirow[t]{2}{*}{6} & \multirow[t]{2}{*}{ WH0402 } & Air $(\sim 386)$ & 8.22 & 0.01 & 2061 & 12 & 395 & 14 \\
\hline & & 750 & 8.05 & 0.01 & 2150 & 18 & 628 & 31 \\
\hline
\end{tabular}

effect between light and $\mathrm{pCO}_{2}$ was not significant $\left(F_{4,18}=0.13, P=0.97\right.$; Fig. $\left.3 c\right)$. Light and $\mathrm{pCO}_{2}$, however, did have a significant positive interactive effect on cellular $\mathrm{CO}_{2}$-fixation rates in cultures of WH0402 $\left(F_{1,20}=13, P=0.002\right.$; Fig. 3d $)$, indicating that the effect of elevated $\mathrm{pCO}_{2}$ significantly increased with increasing light.
Gross cellular $\mathrm{N}_{2}$-fixation rates of $\mathrm{WH} 0401$ were not affected by light between $100-300 \mu \mathrm{E} \mathrm{m}{ }^{-2} \mathrm{~s}^{-1}$ treatments $\left(F_{2,18}=3.0, P=0.1\right)$, or by $\mathrm{pCO}_{2}$ between the present-day and elevated $\mathrm{pCO}_{2}$ treatments $\left(F_{1,18}=0.22, P=0.65\right)$, but were significantly lower in the $190 \mathrm{ppm}$ treatment compared to higher $\mathrm{pCO}_{2}$ treatments $\left(F_{1,18} \geq 7.8, P \leq 0.01\right.$; Fig. $\left.4 a\right)$. Similarly, 

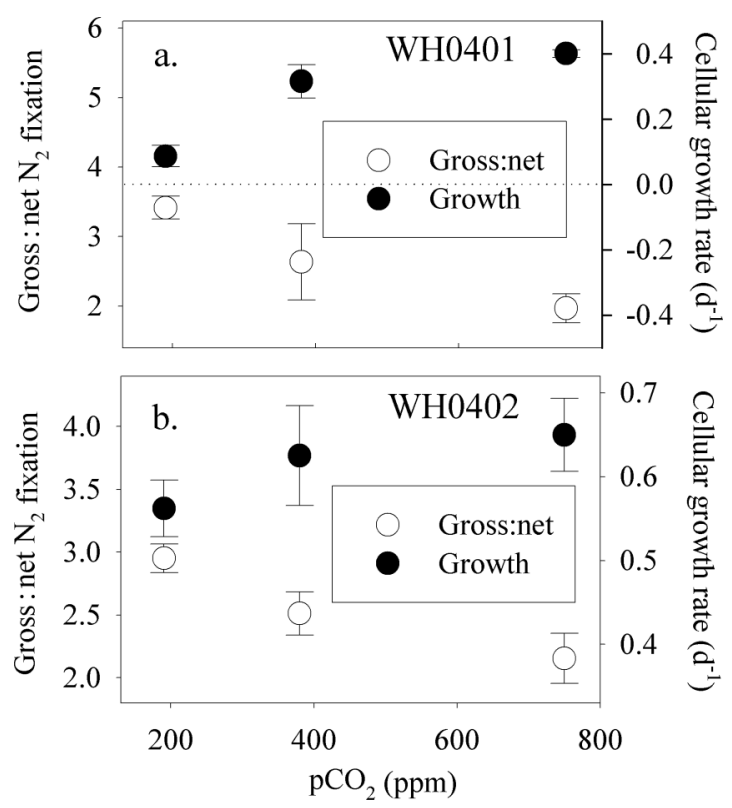

Fig. 2. Specific growth rates and gross : net $\mathrm{N}_{2}$-fixation rate ratios of Crocosphaera watsonii, isolates WH0401 (a) and WH0402 (b), under different $\mathrm{pCO}_{2}$ levels. Data correspond to experiments 3 and 4 in Table 1. Cultures were grown with a semi-continuous culturing method at $155 \mu \mathrm{mol}$ quanta $\mathrm{m}^{-2} \mathrm{~s}^{-1}$. Error bars are the standard errors of the means of three experimental replicates.

for $\mathrm{WH} 0402$, gross cellular $\mathrm{N}_{2}$-fixation rates were not significantly different between the present-day and elevated $\mathrm{pCO}_{2}$ treatments $\left(F_{1,20}=3.1, P=0.09\right.$; Fig. 4b), but significantly increased as a function of increasing light between all light treatments $\left(F_{1,20}>7.2 ; P<0.02\right)$.

Trends in cell-normalized net ${ }^{15} \mathrm{~N}_{2}$-fixation rates by WH0401 were similar to those observed for growth rates: low $\mathrm{pCO}_{2}$ had a significant negative effect on net ${ }^{15} \mathrm{~N}_{2}$-fixation rates in comparison with higher $\mathrm{pCO}_{2}$ levels $\left(F_{1,18} \geq 8.2, P \leq 0.01\right)$ and rates did not differ between the air and elevated $\mathrm{pCO}_{2}$ concentrations $\left(F_{1,18}=0.2, P=0.67\right.$; Fig. $\left.4 \mathrm{c}\right)$. In WH0402, cellnormalized net ${ }^{15} \mathrm{~N}_{2}$-fixation rates were not significantly different between the air and elevated $\mathrm{pCO}_{2}$ treatments $\left(F_{1,20}=0.08, P=0.77\right.$; Fig. $\left.4 \mathrm{~d}\right)$, but were strongly affected by light $\left(F_{4,20}=64 ; P<0.0001\right)$. PNaccumulation rates by $\mathrm{WH} 0401$ were lower than gross $\mathrm{N}_{2}$-fixation rates but considerably higher than net ${ }^{15} \mathrm{~N}_{2}$-fixation rates (Fig. 4e). In WH0402, PN-accumulation rates were similar to gross $\mathrm{N}_{2}$-fixation rates and higher than net ${ }^{15} \mathrm{~N}_{2}$-fixation rates (Fig. 4f; see the Materials and methods section for methodological differences in the acetylene assay between experiments). Both light and $\mathrm{pCO}_{2}$ had significant positive effects on gross $\mathrm{N}$-specific $\mathrm{N}_{2}$-fixation rates by WH0401 $\left(F_{2,18}=26, P<0.001 \quad F_{2,18}=8.0\right.$, $P=0.003$ ) and differences in gross $\mathrm{N}$-specific $\mathrm{N}_{2}$ fixation between the $190 \mathrm{ppm} \mathrm{pCO}_{2}$ treatment and higher $\mathrm{pCO}_{2}$ treatments were more pronounced compared to gross cell-normalized $\mathrm{N}_{2}$-fixation rates (Fig. $4 \mathrm{~g}$ ). In $\mathrm{WH} 0402$, gross $\mathrm{N}$-specific $\mathrm{N}_{2}$-fixation rates were not significantly different between $\mathrm{pCO}_{2}$ treatments and were light saturated near $100 \mu \mathrm{mol}$ quanta $\mathrm{m}^{-2} \mathrm{~s}^{-1}(P>0.05$, Fig. 4h). In both strains, trends in
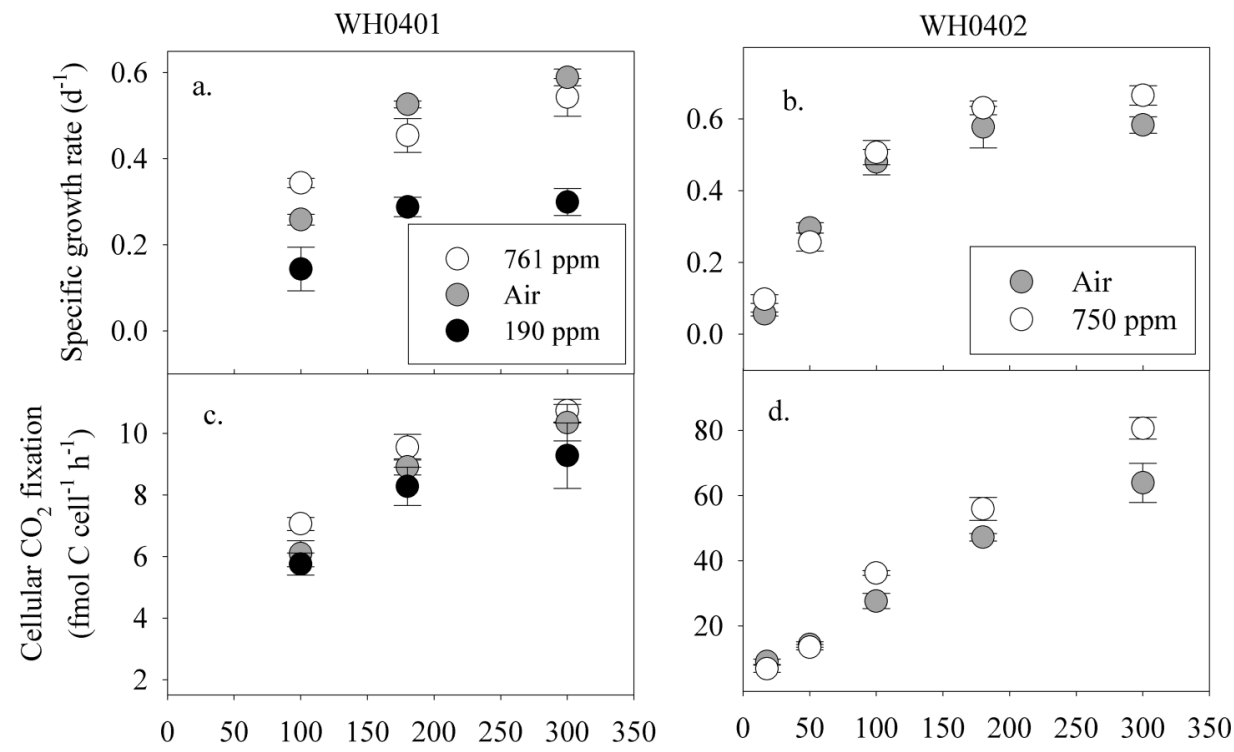

Light $\left(\mu \mathrm{mol}\right.$ quanta $\left.\mathrm{m}^{-2} \mathrm{~s}^{-1}\right)$

Fig. 3. Specific growth rates (a, b) and cellular $\mathrm{CO}_{2}$-fixation rates (c, d) of Crocosphaera watsonii, in semi-continuous cultures grown under a range of light intensities and different $\mathrm{pCO}_{2}$ levels. WH0401 and WH0402 were grown under present-day and elevated $\mathrm{pCO}_{2}$ levels and WH0401 was also grown under $190 \mathrm{ppm} \mathrm{pCO}_{2}$. Data correspond to experiments 5 and 6 in Table 1. Open symbols are 750 or $761 \mathrm{ppm} \mathrm{pCO}_{2}$ treatments; grey symbols are air treatments; closed symbols are $190 \mathrm{ppm} \mathrm{pCO}_{2}$ treatments. Error bars are the standard errors of the means of three experimental replicates. 


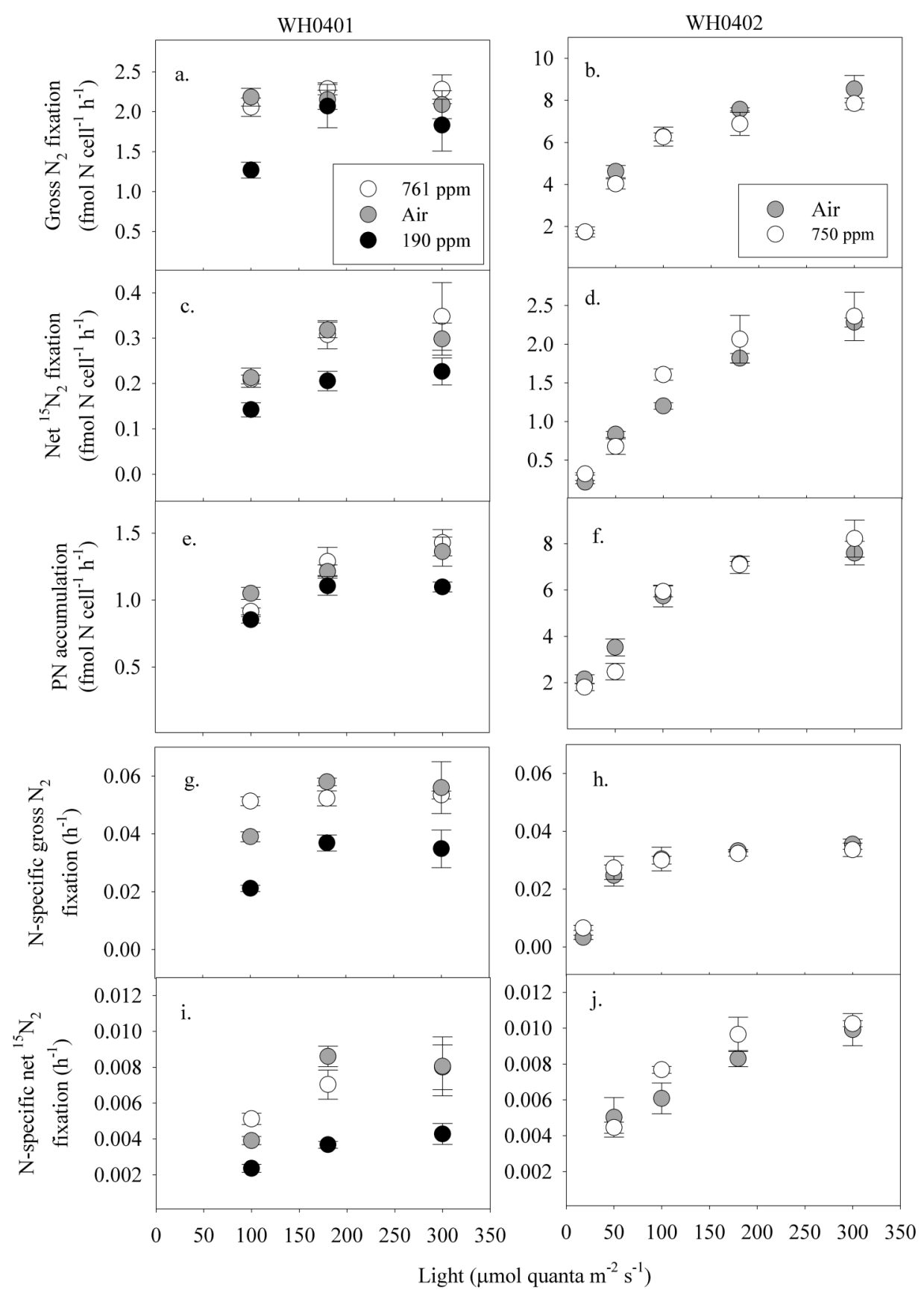

Fig. 4. Cellular gross $\mathrm{N}_{2}$-fixation rates $(\mathrm{a}, \mathrm{b})$, cellular net $\mathrm{N}_{2}$-fixation rates (c, d), calculated cellular particulate nitrogen (PN) accumulation rates $(e, f), \mathrm{N}$-specific gross $\mathrm{N}_{2}$-fixation rates $(\mathrm{g}, \mathrm{h})$, and $\mathrm{N}$-specific net $\mathrm{N}_{2}$-fixation rates (i, j) in semi-continuous cultures of Crocosphaera watsonii, isolates WH0401 and WH0402, as a function of $\mathrm{pCO}_{2}$ and light. WH0401 and WH0402 were grown under present-day and elevated $\mathrm{pCO}_{2}$ levels and $\mathrm{WH} 0401$ was also grown under $190 \mathrm{ppm} \mathrm{pCO}_{2}$. Data correspond to experiments 5 and 6 in Table 1. Open symbols are 750 or 761 ppm $\mathrm{pCO}_{2}$ treatments; grey symbols are air treatments; closed symbols are $190 \mathrm{ppm} \mathrm{pCO}_{2}$ treatments. Error bars are the standard errors of the means of three experimental replicates.

$\mathrm{N}$-specific ${ }^{15} \mathrm{~N}_{2}$-fixation rates (Fig. 4i, j) were very similar to trends in growth rates (Fig. 3a, b).

Both light $\left(F_{2,18}>20.4, P<0.0001\right)$ and $\mathrm{pCO}_{2}$ $\left(F_{2,18}=5.4, P=0.01\right)$ had a significant negative effect on the ratio of gross : net $\mathrm{N}_{2}$ fixation in WH0401 but the interactive effect of light and $\mathrm{pCO}_{2}$ on the ratio was not significant $(P>0.05$; Fig. 5a). In WH0402, light and $\mathrm{pCO}_{2}$ did have a significant interactive effect on the ratio of gross : net $\mathrm{N}_{2}$ fixation; the ratio decreased with increasing light by $53 \%$ in the air treatment but by only $37 \%$ in the $750 \mathrm{ppm} \mathrm{CO}_{2}$ treatment (from 300 to $18 \mu \mathrm{mol}$ quanta $\mathrm{m}^{-2} \mathrm{~s}^{-1}$ ). Thus, the effect of elevated $\mathrm{pCO}_{2}$ on gross : net $\mathrm{N}_{2}$ fixation significantly increased with decreasing light $\left(F_{4,20}=3.9, P=0.02\right.$; Fig. $\left.5 b\right)$, suggesting that the effect of elevated $\mathrm{pCO}_{2}$ on cellular $\mathrm{N}$ retention was strongest under low light. Growth rates of WH0402 were strongly negatively correlated with the gross : net $\mathrm{N}_{2}$-fixation rate ratio $(r=-0.95)$. Light was the most important factor controlling the gross : PN 

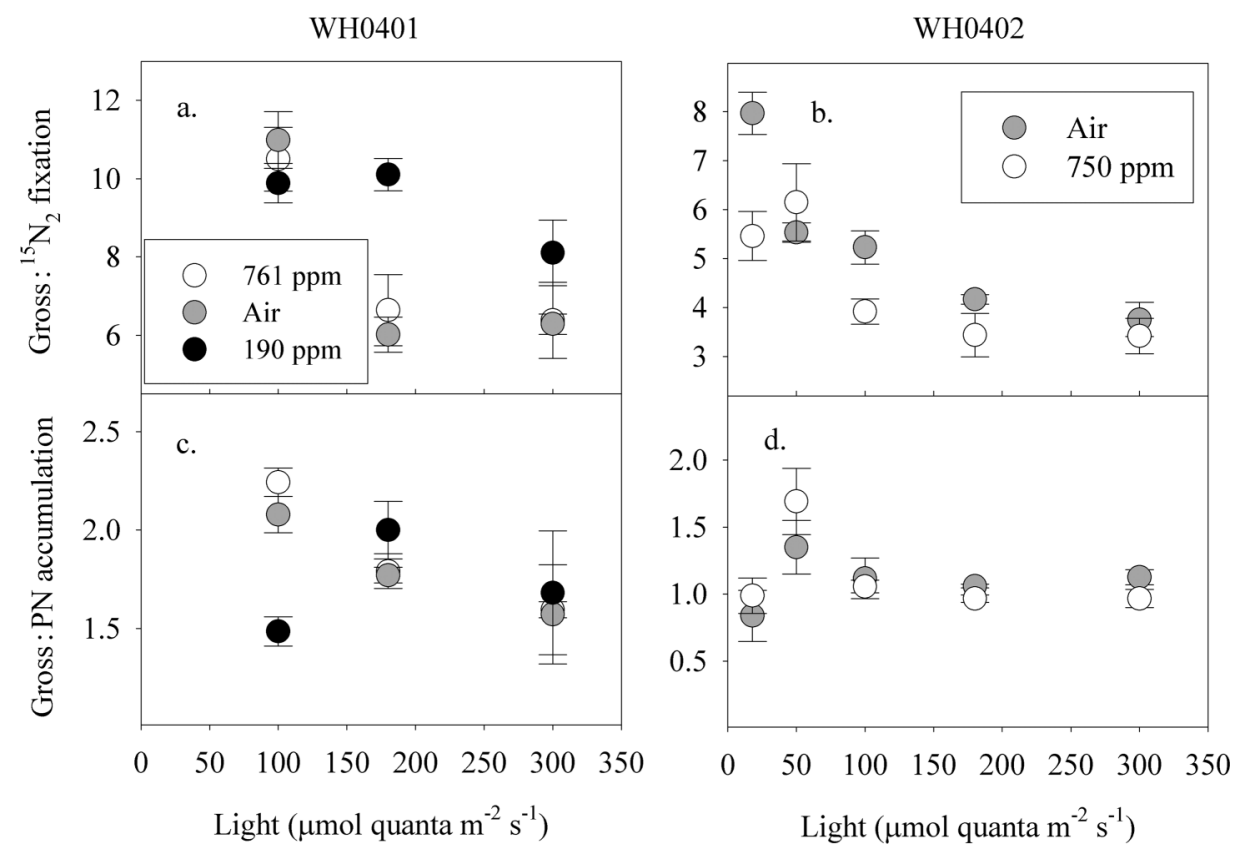

Fig. 5. Gross : net $\mathrm{N}_{2}$-fixation rate ratios $(\mathrm{a}, \mathrm{b})$ and gross : net $\mathrm{PN}$ accumulation ratios $(\mathrm{c}, \mathrm{d})$ in semi-continuous cultures of Crocosphaera watsonii, isolates WH0401 and WH0402, as a function of $\mathrm{pCO}_{2}$ and light. WH0401 and WH0402 were grown under present-day and elevated $\mathrm{pCO}_{2}$ levels and $\mathrm{WH} 0401$ was also grown under $190 \mathrm{ppm} \mathrm{pCO}$. Data correspond to experiments 5 and 6 in Table 1. Open symbols are 750 or 761 ppm pCO 2 treatments; grey symbols are air treatments; closed symbols are $190 \mathrm{ppm} \mathrm{pCO}_{2}$ treatments. Error bars are the standard errors of the means of three experimental replicates.

accumulation ratio in WH0401 $\left(F_{2,18}=3.5, P=0.05\right.$; Fig. 5c), which declined with increasing light. While $\mathrm{pCO}_{2}$ had no effect on the gross : PN accumulation ratio in $\mathrm{WH} 0402\left(F_{1,20}=0.17, P=0.69\right)$, the two-way ANOVA test suggested that light had a significant negative effect on this ratio $\left(F_{4,20}=5.6, P=0.003\right.$; Fig. 5d), although this was driven mostly by the large increase in the ratio at $50 \mu \mathrm{mol}$ quanta $\mathrm{m}^{-2} \mathrm{~s}^{-1}$. In both strains, the range of the gross : $\mathrm{PN}$ accumulation ratio was substantially lower than the range of the gross : net $\mathrm{N}_{2}$-fixation rate ratio (Fig. 5).

\section{Discussion}

Our results identified both similarities and differences in the physiological responses to changing $\mathrm{pCO}_{2}$ and light between large-celled and small-celled strains of Crocosphaera watsonii isolated from the western equatorial region of the Atlantic Ocean. In our light experiments, maximum growth responses $\left(\mu_{\max }\right)$ differed between strains but other Monod functional growth parameters $\left(\mathrm{K}_{\mu}\right.$ and $\left.\mathrm{E}_{\mathrm{c}}\right)$ were similar. Overall, our data indicate that the strain with large cells (WH0402) had higher growth, $\mathrm{N}_{2}$-fixation, and $\mathrm{CO}_{2}-$ fixation rates at near-saturating light, compared to the strain with small cells (WH0401), despite having similar photosynthetic efficiencies at high light (data not shown). These high growth and fixation rates may give $\mathrm{WH} 0402$ an ecological advantage in regions of the ocean where nutrient concentrations are relatively high, whereas the smaller-celled WH0401 strain, with a higher cell surface area : volume ratio, may be better able to survive in lower-nutrient oceanic waters, because it may be able to acquire nutrients more readily when concentrations are low. In both strains, however, the diameters of cells acclimated to high light were $\sim 20 \%$ greater than those acclimated to low light, suggesting that light controls a range of nutrient acquisition rates based on highly plastic cell surface area : volume ratios, as well as cellular quotas of elements.

Our findings do not support previous studies that documented increased growth rates of $C$. watsonii in response to elevated $\mathrm{CO}_{2}$ concentrations when compared to present-day $\mathrm{CO}_{2}$ concentrations (in South Atlantic strain WH8501 from $28^{\circ} \mathrm{S}, 48^{\circ} \mathrm{W}$ : Fu et al., 2008 ); in both of our strains, mean specific growth rates did not differ significantly between the presentday and elevated $\mathrm{pCO}_{2}$ treatments under any of the light levels that we tested. The growth rates of WH0401, however, were significantly lower under low $\mathrm{pCO}_{2}(190 \mathrm{ppm})$ at all light levels (100-300 $\mu$ mol quanta $\left.\mathrm{m}^{-2} \mathrm{~s}^{-1}\right)$ than in treatments with higher $\mathrm{pCO}_{2}$, whereas the growth rates of WH0402 were only slightly lower at low $\mathrm{pCO}_{2}$ and near-saturating light $\left(155 \mu\right.$ mol quanta $\left.\mathrm{m}^{-2} \mathrm{~s}^{-1}\right)$ when compared to higher $\mathrm{pCO}_{2}$ treatments. These data suggest that WH0402 has a low $\mathrm{K}_{\mu}$ for growth with respect to $\mathrm{pCO}_{2}$ compared to $\mathrm{WH} 0401$, and also that the present-day concentration of $\mathrm{pCO}_{2}$ is near growth-saturating levels for both strains. We do not know why growth rates of WH0401 were lower in the $\mathrm{CO}_{2}$ experiment (experiment 3) than in the $\mathrm{CO}_{2}$-light experiment (experiment 5) but the $\mathrm{CO}_{2}$ experiments with WH0401 and WH0402 were done in parallel and 
provide comparative data between these strains. Collectively, these data support the notion that there may be strong differences between strains of Crocosphaera in terms of their ability to sequester inorganic carbon.

\section{Mechanistic effect of elevated $\mathrm{CO}_{2}$ on $\mathrm{N}_{2}$-fixation rates}

Several authors have suggested that $\mathrm{N}_{2}$-fixation rates in Trichodesmium benefit from elevated $\mathrm{pCO}_{2}$ by higher rates of diffusion of $\mathrm{CO}_{2}$ across the cell membrane (Barcelos e Ramos et al., 2007; Hutchins et al., 2007; Levitan et al., 2007, Kranz et al., 2009, 2010; Garcia et al., 2011). These higher rates then decrease the energy demand associated with active transport of bicarbonate $\left(\mathrm{HCO}_{3}{ }^{-}\right)$, the main source of inorganic carbon that fuels $\mathrm{CO}_{2}$ fixation in both Trichodesmium and Crocosphaera (Giordano et al., 2005; Badger et al., 2006; Price et al., 2008). This 'saved' energy might then be used to support high $\mathrm{CO}_{2}$-fixation and $\mathrm{N}_{2}$-fixation rates. This model must be modified for dark $\mathrm{N}_{2}$ fixers like Crocosphaera, however, because cellular inorganic carbon uptake is driven by light (Badger et al., 2006). Thus, the indirect effect of elevated $\mathrm{pCO}_{2}$ on $\mathrm{N}_{2}$ fixation by Crocosphaera seems to be to allow the cell to accumulate larger photosynthate reserves during the preceding light period and the energy acquired from respiration of those reserves can then be used to drive $\mathrm{N}_{2}$ fixation during the dark hours.

Studies of eukaryotic phytoplankton have supported this model for cellular energetic benefits from elevated $\mathrm{pCO}_{2}$, suggesting that a doubled $\mathrm{pCO}_{2}$ could lead to a saving of $\sim 20 \%$ of the energy consumed by the CCM, or up to $6 \%$ of the total cellular energy budget (Hopkinson et al., 2011). Further studies are needed to confirm this in Trichodesmium and Crocosphaera, however, because some data suggest that inorganic $\mathrm{C}$ cycling in other cyanobacteria is related to light energy dissipation rather than $\mathrm{CO}_{2}$ saturation of Rubisco and that cells may constitute a source of $\mathrm{CO}_{2}$ rather than a sink (Tchernov et al., 1998, 2003).

\section{Potential effects of cell size}

Differing abilities to acquire inorganic carbon could be related to cell size. Larger cells have a lower surface area : volume ratio than smaller cells, and so have lower volume-normalized $\mathrm{CO}_{2}$ diffusion rates into the cell. However, in our study, the strain with larger cells (WH0402) seemed to have a lower $\mathrm{K}_{\mu}$ with respect to $\mathrm{CO}_{2}$. Assuming that differences in $\mathrm{K}_{\mu}$ are proportional to $\mathrm{K}_{1 / 2}$ for $\mathrm{CO}_{2}$ between strains, it is apparent that simple diffusion-based surface area : volume relationships cannot explain our results. New physicochemical modelling (Flynn et al., 2012) suggests that as phytoplankton cell size increases, $\mathrm{pH}$ changes in the bulk medium have less physiological effect because the chemistry of the cell's diffusive boundary layer is progressively more influenced by cellular metabolic processes. Differences in $\mathrm{K}_{\mu}$ with respect to $\mathrm{CO}_{2}$ might also be caused by differences in the efficiency of transmembrane $\mathrm{HCO}_{3}^{-}$-transport systems, but such attribution of cause and effect must await further studies with multiple $C$. watsonii isolates. Although Price et al. (2008) identified different mechanisms by which strain WH8501 acquires carbon, there is no literature describing differences in these mechanisms between this and other isolates of $C$. watsonii.

It is also possible that a higher $\mathrm{CO}_{2}$ diffusion rate for larger cells might be facilitated by the existence of acidic zones around the cell, as suggested by Raven et al. (2008). Future studies should investigate this possibility for large-celled strains of $C$. watsonii, given the much larger amounts of potentially acidic extracellular polysaccharide exudates associated with large-celled strains, compared to small-celled strains (Webb et al., 2009; Sohm et al., 2011). In addition, strain-specific differences might be caused by biogeochemical differences between their sites of origin; for instance WH0401 was collected near the Amazon River plume, and WH0402 is likely not adapted to this type of terrestrially influenced environment. Further studies should address the global diversity of $\mathrm{N}_{2}$-fixing cyanobacteria such as Crocosphaera in relation to changing $\mathrm{pCO}_{2}$, as our work makes it clear that even closely related strains of a diazotrophic species may have very different responses to the environmental changes that will occur in a future acidifying and warming ocean.

\section{Gross : net $N_{2}$ fixation ratios}

Mean gross : net $\mathrm{N}_{2}$-fixation rate ratios were negatively correlated with mean growth rates, suggesting that high light and high $\mathrm{pCO}_{2}$ enhanced the incorporation of fixed $\mathrm{N}_{2}$ into biomass when growth rates were maximal. Thus, based on previous studies of cellular $\mathrm{N}$ retention (Mulholland et al., 2004; Mulholland, 2007), we infer that the loss of fixed $\mathrm{N}$ might be minimized in a high light, high $\mathrm{pCO}_{2}$ environment. Assuming that $C$. watsonii will be grazed upon to a significant degree in the future, we might expect nitrogen to flow more efficiently through food webs within the next 100 years, thereby fuelling higher secondary and tertiary production rates. For instance, a high rate of $\mathrm{N}$ loss would tend to favour production within the microbial loop, thereby decreasing the efficiency of $\mathrm{N}$ transfer to higher trophic levels. These higher secondary and tertiary production rates may, in turn, accelerate carbon drawdown from surface layers of the oceans.

Recently, Mohr et al. (2010b) have addressed potential problems associated with the execution of 
the ${ }^{15} \mathrm{~N}_{2}$ isotope uptake method, suggesting that gas solubility issues can potentially lead to large underestimates of actual net $\mathrm{N}_{2}$-fixation rates if the technique is not applied properly. The $\mathrm{PN}$ accumulation rate is another method that estimates net $\mathrm{N}_{2}$-fixation rates (Kranz et al., 2009). In our experiments, the gross : PN accumulation ratio was close to 1 at light levels that were non-limiting to growth. A ratio of 1 seems more reasonable than the very high estimates of the gross : net $\mathrm{N}_{2}$-fixation rate ratios (up to 15 ) that we documented using the isotope uptake method. But in support of the ${ }^{15} \mathrm{~N}_{2}$ isotope uptake method, ${ }^{15} \mathrm{~N}_{2}$-fixation rates and growth rates were strongly correlated in all of our experiments. In addition, ${ }^{15} \mathrm{~N}_{2}$ injections probably equilibrated with non-isotope $\mathrm{N}_{2}$ gas during our 12-h incubations. We note that gross $\mathrm{N}_{2}$-fixation rates in the $\mathrm{CO}_{2}$-light experiment with WH0401 were amplified, in comparison with other experiments, because of the modification of the acetylene assay (see $\mathrm{N}_{2}$ fixation in the Materials and methods section). These higher gross $\mathrm{N}_{2}$-fixation rates amplified gross : net ratios in the $\mathrm{CO}_{2}$-light experiment with WH0401. Because the method for the acetylene assay technique was the same in the light and $\mathrm{CO}_{2}$ experiments, our best comparisons of the gross : net $\mathrm{N}_{2}$-fixation rate ratios between strains are those shown in Figs 1 and 2.

In summary, the growth rates of the large-celled strain (WH0402) were higher than those observed for the smaller-celled strain (WH0401). Our data also imply that WH0402 might have a stronger ability to sequester inorganic carbon than WH0401 at $155 \mu \mathrm{E}$ $\mathrm{m}^{-2} \mathrm{~s}^{-1}$. This conclusion is based on the difference in growth rate reduction between isolates in response to low $\mathrm{pCO}_{2}$ compared to air treatments in the $\mathrm{CO}_{2}$ experiments (experiments 3 and $4 ; \geq 40 \%$ for WH0401; $10-15 \%$ for WH0402). These data indicate that $\mathrm{K}_{\mu}$ for WH0401 with respect to $\mathrm{CO}_{2}$ might be close to or higher than $190 \mathrm{ppm} \mathrm{pCO}$, whereas that for WH0402 is lower. A strong ability to sequester inorganic carbon may be the reason that $\mathrm{WH} 0402$ has higher growth, $\mathrm{N}_{2}$-fixation and $\mathrm{CO}_{2}$-fixation rates than WH0401.

Our study suggests that unicellular diazotrophic cyanobacteria may have strain-specific responses to interacting variables such as $\mathrm{CO}_{2}$ and light. Similar differences may exist in the responses of different strains to changes in temperature, or the availability of essential nutrients such as phosphorus and iron, as well as to the interactions between all of these factors. Because global change in the ocean involves simultaneous shifts in each of these variables, our work emphasizes the need to understand multivariate effects in the context of the diversity within the genus Crocosphaera, rather than making broad generalizations based on studies using only single isolates.

\section{Acknowledgements}

We thank Dr Eric Webb for providing isolates of C. watsonii for our experiments and also for allowing us to use his gas chromatograph for the acetylene reduction assay. Grant support was provided by NSF OCE 0942379, 0962309 and 1043748 to D. Hutchins, NSF OCE 0850730 to F.-X. Fu, and NSF OCE 0722395 to M. Mulholland.

\section{References}

Alley, R.B., Berntsen, T., Bindoff, N.L., Chen, Z., Chidthaisong, A., Friedlingstein, P., Gregory, J.M., Hegerl, G.C., Heimann, M., Hewitson, B., Hoskins, B.J., Joos, F., Jouzel, J., Kattsov, V., Lohmann, U., Manning, M., Matsuno, T., Molina, M., Nicholls, N., Overpeck, J., Qin, D., Raga, G., Ramaswamy, V., Ren, J., Rusticucci, M., Solomon, S., Somerville, R., Stocker, T.F., Stott, P.A., Stouffer, R.J., Whetton, P., Wood, R.A. \& Wratt, D. (2007). Summary for policymakers. In Climate change 2007: The physical science basis. Contribution of Working Group I to the fourth assessment report of the Intergovernmental Panel on Climate Change (Solomon, S., Qin, D., Manning, M., Chen, Z., Marquis, M., Averyt, K.B., Tignor, M. \& Miller, H.L., editors), 1-18. Cambridge University Press, Cambridge.

Badger, M.R., Price, G.D., Long, B.M. \& Woodger, F.J. (2006). The environmental plasticity and ecological genomics of the cyanobacterial $\mathrm{CO}_{2}$ concentrating mechanism. Journal of Experimental Botany, 57: 249-265.

Barcelos e Ramos, J., Biswas, H., Schulz, K.G., LaRoche, J. \& Riebesell, U. (2007). Effect of rising atmospheric carbon dioxide on the marine nitrogen fixer Trichodesmium. Global Biogeochemical Cycles, 21: GB2028.

Behrenfeld, M.J., O’Mally, R.T., Siegel, D.A., McClain, C.R., Sarmiento, J.L., Feldman, G.C., Milligan, A.J., Falkowski, P.G., Letelier, R.M. \& Boss, E.S. (2006). Climate-driven trends in contemporary ocean productivity. Nature, 444: 752-755.

Boyd, P.W., StrzepeK, R., Fu, F. \& Hutchins, D.A. (2010). Environmental control of open-ocean phytoplankton groups: now and in the future. Limnology and Oceanography, 55: 1353-1376.

Breitbarth, E., Mills, M.M., Friedrichs, G. \& LaRoche, J. (2004). The Bunsen gas solubility coefficient of ethylene as a function of temperature and salinity and its importance for nitrogen fixation assays. Limnology and Oceanography: Methods, 2: 282-288.

CAPONE, D.G. (1993). Determination of nitrogenase activity in aquatic samples using the acetylene reduction procedure. In Handbook of Methods in Aquatic Microbial Ecology (Kemp, P.F., Cole, J.J., Sherr, B.F. \& Sherr, E.B., editors), 621-631. Lewis Publishers, Boca Raton, FL.

CApone, D.G. (2008). The marine nitrogen cycle. Microbe, 3: 186192.

Chen, Y.B., Zehr, J.P. \& Mellon, M. (1996). Growth and nitrogen fixation of the diazotrophic filamentous nonheterocystous cyanobacterium Trichodesmium sp. IMS101 in defined media: evidence for a circadian rhythm. Journal of Phycology, 32: 916-923.

Church, M.J., Buörkman, K.M., Karl, D.M., Saito, M.A. \& Zehr, J.P. (2008). Regional distributions of nitrogen-fixing bacteria in the Pacific Ocean. Limnology and Oceanography, 53: 63-77.

Deutsch, C., Sarmiento, J.L., Sigman, D.M., Gruber, N. \& Dunne, J.P. (2007). Spatial coupling of nitrogen inputs and losses in the ocean. Nature, 445: 163-167.

Dickson, A.G. \& Millero, F.J. (1987). A comparison of the equilibrium constants for the dissociation of carbonic acid in seawater media. Deep-Sea Research, 34: 1733-1743.

Flynn, K.J., Blackford, J.C., Bairds, M.E., Raven, J.A., Clark, D.R., Beardall, J., Brownlee, C., Fabian, H. \& Wheeler, G.L. (2012). Changes in $\mathrm{pH}$ at the exterior surface of plankton with ocean acidification. Nature Climate Change, 2: 510-513. 
Fu, F.-X., Mulholland, M.R., Garcia, N.S., Beck, A., Bernhardt, P.W., Warner, M.E., SAnudo-Wilhelmy, S.A. \& Hutchins, D.A (2008). Interactions between changing $\mathrm{pCO}_{2}, \mathrm{~N}_{2}$ fixation, and $\mathrm{Fe}$ limitation in the marine unicellular cyanobacterium Crocosphaera. Limnology and Oceanography, 53: 2472-2484.

Garcia, N.S., Fu, F.-X., Breene, C.L., Bernhardt, P.W., Mulholland, M.R., Sohm, J.A. \& Hutchins, D.A. (2011). Interactive effects of irradiance and $\mathrm{CO}_{2}$ on $\mathrm{CO}_{2}-$ and $\mathrm{N}_{2}$ fixation in the diazotroph Trichodesmium erythraeum (Cyanobacteria). Journal of Phycology, 47: 1292-1303.

Giordano, M., Beardall, J. \& Raven, J.A. (2005). CO 2 concentrating mechanisms in algae: mechanisms, environmental modulation, and evolution. Annual Review of Plant Biology, 56: 99-131.

Goebel, N.L., Edwards, C.A., Church, M.J. \& Zehr, J.P. (2007). Modeled contributions of three types of diazotrophs to nitrogen fixation at Station ALOHA. ISME Journal, 1: 606-619.

Goebel, N.L., Edwards, C.A., Carter, B.J., Achilles, K.M. \& Zehr, J.P. (2008). Growth and carbon content of three different-sized diazotrophic cyanobacteria observed in the subtropical North Pacific. Journal of Phycology, 44: 1212-1220.

Hopkinson, B.M., Dupont, C.L., Allen, A.E. \& Morel, F.M.M. (2011). Efficiency of the $\mathrm{CO}_{2}$-concentrating mechanisms of diatoms. Proceedings of the National Academy of Sciences of the United States of America, 108: 38030-38037.

Hutchins, D.A., Fu, F.X., Zhang, Y., Warner, M.E., Feng, Y., Portune, K., Bernhardt, P.W. \& Mulholland, M.R. (2007). $\mathrm{CO}_{2}$ control of Trichodesmium $\mathrm{N}_{2}$-fixation, photosynthesis, growth rates, and elemental ratios: implications for past, present, and future ocean biogeochemistry. Limnology and Oceanography, 52: 1293-1304.

Hutchins, D.A., Mulholland, M.R. \& Fu, F.-X. (2009). Nutrient cycles and marine microbes in a $\mathrm{CO}_{2}$ enriched ocean. Oceanography, 22: 128-145.

Kranz, S.A., Sultemeyer, D., Richter, K.U. \& Rost, B. (2009). Carbon acquisition by Trichodesmium: the effect of $\mathrm{pCO}_{2}$ and diurnal changes. Limnology and Oceanography, 54: 548-559.

Kranz, S.A., Levitan, O., Richter, K-U., Prášill, O., BermanFrank, I. \& Rost, B. (2010). Combined effects of $\mathrm{CO}_{2}$ and light on the $\mathrm{N}_{2}$-fixing cyanobacterium Trichodesmium IMS101: physiological responses. Plant Physiology, 154: 334-345.

Levitan, O., Rosenberg, G., Setlik, I., Setlikova, E., Grigel, J., Klepetar, J., Prášill, O. \& Berman-Frank, I. (2007). Elevated $\mathrm{CO}_{2}$ enhances nitrogen fixation and growth in the marine cyanobacterium Trichodesmium. Global Change Biology, 13: $531-538$.

Levitan, O., Kranz, S. A., Spungin, D., Prášill, O., Rost, B. \& Berman-Frank, I. (2010). Combined effects of $\mathrm{CO}_{2}$ and light on the $\mathrm{N}_{2}$-fixing cyanobacterium Trichodesmium IMS101: a mechanistic view. Plant Physiology, 154: 346-356.

Lewis, E. \& Wallace, D.W.R. (1998). Program developed for $\mathrm{CO}_{2}$ System calculations. ORNL/CDIAC-105. Carbon Dioxide Information Analysis Center, Oak Ridge National Laboratory, U. S. Department of Energy, Oak Ridge, Tennessee. Available at: http://cdiac.ornl.gov/oceans/co2rprt.html.

Mehrbach, Y., Culberson, C., Hawley, J. \& Pytkowicz, R. (1973). Measurement of the apparent dissociation constants of carbonic acid in seawater at atmospheric pressure. Limnology and Oceanography, 18: 897-907.

Mohr, W., Intermaggio, M.P. \& LaRoche, J. (2010a). Diel rhythm of nitrogen and carbon metabolism in the unicellular, diazotrophic cyanobacterium Crocosphaera watsonii WH8501. Environmental Microbiology, 12: 412-421.

Mohr, W., Großkopf, T., Wallace, D.W.R. \& LaRoche, J. (2010b). Methodological underestimation of oceanic nitrogen fixation rates. PLOS ONE, 5: e12583.

Moisander, P.H., Beinart, R.A., Hewson, I., White, A.E., Johnson, K.S., Carlson, C. A., Montoya, J.P. \& Zehr, J.P. (2010). Unicellular cyanobacterial distributions broaden the oceanic $\mathrm{N}_{2}$ fixation domain. Science, 327: 1512-1514.
Monod, J. (1949). The growth of bacterial cultures. Annual Review of Microbiology, 3: 371-394.

Montoya, J.P., Holl, C.M., Zehr, J.P., Hansen, A., Villareal, T.A. \& CAPONE, D.G. (2004). High rates of $\mathrm{N}_{2}$ fixation by unicellular diazotrophs in the oligotrophic Pacific Ocean. Nature, 430: 1027-1031.

Morel, F.M.M., Rueter, J.G., Anderson, D.M. \& Guillard, R.R.L. (1979). Aquil: a chemically defined phytoplankton culture-medium for trace-metal studies. Journal of Phycology, 15: $135-141$.

Mulholland, M.R. (2007). The fate of nitrogen fixed by diazotrophs in the ocean. Biogeosciences 4: 37-51.

Mulholland, M.R. \& Bernhardt, P.W. (2005). The effect of growth rate, phosphorus concentration and temperature on $\mathrm{N}_{2}$-fixation, carbon fixation, and nitrogen release in continuous cultures of Trichodesmium IMS101. Limnology and Oceanography, 50: 839-849.

Mulholland, M.R., Bronk, D.A. \& Capone, D.G. (2004). N 2 fixation and regeneration of $\mathrm{NH}_{4}{ }^{+}$and dissolved organic $\mathrm{N}$ by Trichodesmium IMS101. Aquatic Microbial Ecology, 37: 85-94. Mulholland, M.R., Bernhardt, P.W., Blanco-Garcia, J.L., Maninno, A., Hyde, K., Mondragon, E., Turk, K., Moisander, P.H. \& ZeHr, J.P. (2012). Rates of dinitrogen fixation and the abundance of diazotrophs in North American coastal waters between Cape Hatteras and Georges Bank. Limnology and Oceanography, 57: 1067-1083.

Petit, J.R., Jouzel, J., Raynaud, D., Barkov, N.I., Barnola, J.-M., Basile, I., Bender, M., Chapellaz, J., Davis, M., Delaygue, G., Delmott, M., Kotlyakov, V.M., Legrand, M., Lipenkov, V.Y., Lorius, C., Pépin, L., Ritz, C., Saltzman, E. \& Stievenard, M. (1999). Climate and atmospheric history of the past 420,000 years from the Vostok ice core, Antarctica. Nature, 399: 429-436.

Price, G.D., Badger, M.R., Woodger, F.J. \& Long, B.M. (2008). Advances in understanding the cyanobacterial $\mathrm{CO}_{2}$-concentratingmechanism (CCM): functional components, Ci transporters, diversity, genetic regulation and prospects for engineering into plants. Journal of Experimental Botany, 59: 1441-1461.

Raven, J.A., Giordano, M. \& Beardall, J. (2008). Insights into the evolution of CCMs from comparisons with other resource acquisition and assimilation processes. Physiologia Plantarum, 133: 4-14. Saito, M.A., Bertrand, E.M., Dutkiewics, S., Bulygen, V.V., Moran, D.M., Montiero, F.M., Follows, M.J., Valois, F.W. \& WATERBURY, J.B. (2011). Iron conservation by reduction of metalloenzyme inventories in the marine diazotroph Crocosphaera watsonii. Proceedings of the National Academy of Sciences of the United States of America, 108: 2184-2189.

Sarmiento, J.L., Slater, R., Barber, R., Bopp, L., Doney, S.C., Hirst, A.C., Kleypas, J., Matear, R., Mikolajewics, U., Monfrey, P., Soldatov, V., Spall, S.A. \& Stouffer, R. (2004). Response of ocean systems to climate warming. Global Biogeochemical Cycles, 18 (3): GB3003. doi:10.1029/ 2003 GB002134.

Sohm, J.A., Edwards, B.R., Wilson, B.G. \& WebB, E.A. (2011). Constitutive extracellular polysaccharide (EPS) production by specific isolates of Crocosphaera watsonii. Frontiers in Microbiology, 2 (229). doi: 10.3389/fmicb.2011.00229

Tchernov, D., Hassidim, M., Vardi, A., Luz, B., Sukenik, A., Reinhold, L. \& Kaplan, A. (1998). Photosynthesizing marine microorganisms can constitute a source of $\mathrm{CO}_{2}$ rather than a sink. Canadian Journal of Botany, 76: 949-953.

Tchernov, D., Silverman, J., Luz, B., Reinhold, L. \& Kaplan, A. 2003. Massive light-dependent cycling of inorganic carbon between oxygenic photosynthetic microorganisms and their surroundings. Photosynthesis Research, 77: 95-103.

Webb, E.A., Ehrenreich, I.M., Brown, S.L., Valois, F.W. \& WAterbury, J. B. (2009). Phenotypic and genotypic characterization of multiple strains of the diazotrophic cyanobacterium Crocosphaera watsonii, isolated from the open ocean. Environmental Microbiology, 11: 338-348. 
Zehr, J.P., Waterbury, J.B., Turner, P.J., Montoya, J.P., Omoregie, E., Steward, G.F., Hansen, A. \& KarL, D.M. (2001). Unicellular cyanobacteria fix $\mathrm{N}_{2}$ in the subtropical North Pacific Ocean. Nature, 412: 635-638.
Zehr, J.P., Bench, S.R., Monragon, E.A., McCarren, J. \& Delong, E.F. (2007). Low genomic diversity in tropical oceanic $\mathrm{N}_{2}$-fixing cyanobacteria. Proceedings of the National Academy of Sciences of the United States of America, 104: 17807-17812. 